\title{
Housing First: Lessons from the United States and Challenges for Australia
}

\author{
Stefan G. Kertesz and Guy Johnson* \\ * Kertesz: Birmingham Veterans Administration Medical Center, U.S. Department of Veterans \\ Affairs, Alabama 35233 United States, and School of Medicine, University of Alabama at \\ Birmingham, Alabama 35205 United States; Johnson: Centre for Applied Social Research, RMIT \\ University, Victoria 3000 Australia. Corresponding author: Kertesz, email <skertesz@uabmc.edu>.
}

\section{Abstract}

Efforts to end long-term homelessness have embraced a Housing First approach. Housing First emphasises rapid placement of clients into independent, permanent accommodation and eschews traditionally favoured requirements that clients demonstrate sobriety or success in treatment programs prior to being offered housing. Although housing retention rates are superior to those obtained from traditional programs, some claims made on behalf of the Housing First approach remain controversial. The present article reviews results from Housing First research to date, as well as challenges and concerns that remain in regard to clinical outcomes, fidelity of implementation and application in the Australian context.

This is the author manuscript accepted for publication and has undergone full peer review but has not been through the copyediting, typesetting, pagination and proofreading process, which may lead to differences between this version and the Version of Record. Please cite this article as doi: $10.1111 / 1467-8462.12217$ 


\section{Introduction}

The prevalence of visible homelessness has spurred increased policy attention on developing Housing First initiatives for chronically homeless individuals. The expression 'Housing First' is applied when programs combine permanent community-based housing with support services that assist chronically homeless individuals to sustain their housing and work toward a community-based recovery and reintegration. Housing First eschews traditional 'linear model' preconditions of sobriety or treatment before individuals are offered independent accommodation (O'Connell, Kasprow and Rosenheck 2009; Johnsen and Teixeira 2010). An implicit assumption in the linear approach is that chronically homeless people cannot sustain accommodation without 'restoration of behavioural self-regulation' (Kertesz et al. 2009, p. 500), yet Housing First initiatives have attained superior housing outcomes, compared to linear approaches. Indeed, the success of Housing First in the United States has resulted in worldwide interest.

Despite credible housing outcomes, a number of issues remain unsettled. For example, uncertainty surrounds the question of whether Housing First programs can reliably confer significant medical and behavioural benefits. Additionally, contradictory evidence besets the attractive claim that it costs less to house chronically homeless individuals than to leave them homeless. Successful implementation of Housing First remains a complex undertaking that involves collaboration across domains such as health, housing and public finance. These complexities mean that findings may not apply across national or cultural boundaries (Durlak and DuPre 2008; Busch-Geertsema 2014). This may be important for 
countries, such as Australia, since Housing First emerged in North America. This article examines how developments in North America, both of the Housing First model and the evidence base, align with the Australian experience.

\section{Background}

\subsection{Definition and Enumeration}

There is no universally accepted definition of homelessness. The most common US definition is limited to people sleeping outdoors or in other places not meant for habitation and those residing in temporary shelters. In contrast, Australian policymakers favour a broad definition that encompasses people living temporarily with family and friends, as well as those living in severely overcrowded housing. The Australian Bureau of Statistics estimated there were 105,237 homeless persons in 2011 , with 6,813 (or 6 per cent) sleeping outdoors or in places not meant for habitation (Australian Bureau of Statistics 2012). In the United States, there were 549,928 persons who were homeless on a single night in January 2016 , with just under one-third (32 per cent) sleeping outdoors or in a place unfit for human habitation (Office of Community Planning and Development 2016). Most people who experience homelessness have a single episode, but some become chronically mired in homelessness. This highlights another important difference between the two countries: the United States has an official definition of chronic homelessness, whereas Australia does not. In the United States, it is estimated that chronically homeless persons account for approximately 15 per cent of the homeless population 
but because chronic homelessness is not defined in Australia, policy-makers often use counts of people sleeping outdoors (rough sleepers) as a proxy (Parsell 2014).

Among the long-term homeless, the prevalence of substance misuse and mental health issues is high, as is the likelihood of sexual or physical victimisation and traumatic brain injury. Although the physical health of the long-term homeless is poor, classic illnesses of social deprivation (tuberculosis, trench fever, pellagra) are dwarfed by morbidity and mortality attributable to more common illnesses of advanced societies: physical trauma, heart disease, cancer and drug overdose (Baggett et al. 2013). Additionally, homeless persons accrue costly services across the health, social service and criminal justice sectors (Culhane, Metraux and Hadley 2002), each of which represents a publicly funded crash landing for persons whose life is frequently chaotic.

\section{Housing First}

\subsection{Rationale and Definition}

Housing First emerged because of shortfalls in what was achieved by the more traditional stairway, or linear approach, in which clients had to proceed through sequential care settings (emergency shelter, residential recovery program).

Successful participation in treatment for behavioural problems was construed as making the client 'housing-ready', so as to avoid crises after an eventual placement. The approach suffered shortfalls, reflected in data suggesting roughly $30-50$ per cent of clients achieved housing after 1-2 years (Kertesz et al. 2009). 
Problems affecting the linear programs seem predictable in retrospect. Some clients required housing but were unwilling or unable to participate in typical groupbased residential treatment programs. Others lacked a substance use or mental disorder and were excluded from linear programs altogether. Patients with addictions could not always achieve levels of abstinence desired by housing providers, with the result that successfully treated populations often remained homeless (Kertesz et al. 2007).

Housing First approaches treat housing as a human right and prioritises client agency in determining what kinds of treatments are attempted (Tsemberis 2010). Because the terms 'permanent supportive housing', 'supported housing' and 'Housing First' are often used interchangeably (Tabol, Drebing and Rosenheck 2010), some clarification is needed. Some refer to 'permanent supportive housing' as any housing arrangement that includes housing and services (Lipton et al. 2000), regardless of the treatment approach. Others affirm that a permanent supportive housing approach should explicitly draw on Housing First practices. Generally, a Housing First approach includes these key features: (i) the absence of sobriety or treatment preconditions for housing; (ii) an emphasis on rapid placement into permanent housing; and (iii) the assurance of sufficient support services in a community context, understanding that the intensity and duration of these services (including potential graduation) depend both on client need and self-determination.

The US-based Pathways to Housing Program (Tsemberis 2010), often considered an exemplar of the Housing First approach, includes some additional elements, some of which have been embraced by others. These include: (i) a modern philosophy of harm reduction, coupled with client engagement through motivational interviewing (Miller and Rollnick 2004); (ii) physical and programmatic This article is protected by copyright. All rights reserved 
separation of housing and services (thus eschewing single-building accommodation); and (iii) an emphasis on community reintegration. Finally, some (though not all) Housing First initiatives recruit persons perceived to have the greatest medical vulnerability or the greatest barriers to housing success.

Housing delivery varies across Housing First programs. The scattered-site approach provides financial support for private market rental units, with staff who check in with the client and broker services. This approach is tied to an expectation that chronically homeless people want to live in normal housing in normal neighbourhoods (Stefancic and Tsemberis 2007). A project-based approach clusters clients in a single apartment building, with services on the first floor or nearby (Larimer et al. 2009; Collins et al. 2012). For some clients, it offers a sense of community and reduces transit time for caregivers. However, such congregate arrangements can sometimes draw neighbourhood opposition and/or prove difficult to manage.

\subsection{Implementation}

Adoption of Housing First faces numerous organisational and clinical challenges.

Communities and front-line staff require material support and cross-agency collaboration to select clients, search for landlords, secure move-in funds and furniture, provide interim shelter and deliver clinical support (Austin et al. 2014). Leaders of government and non-governmental services can provide impetus and help to assure integration of effort between and within agencies (Kertesz et al. 2014). When Housing First is interpreted to mean only the relaxation of traditional 
expectations for housing entry, absent robust service supports, disappointment, eviction and blowback are likely (Kertesz et al. 2015).

Formal analyses of fidelity to the Housing First approach are uncommon (Benston 2015). While some programs have trouble eliminating traditional preconditions (Gilmer et al. 2015), a common vulnerability is the assurance of adequate treatment and recovery supports (Macnaughton et al. 2015; Austin, Pollio and Kertesz 2016). Challenges include the assurance of an appropriate staff-to-client ratio and accessibility $24 \mathrm{~h}$ per day, 7 days per week. Also, front-line staff may adopt a passive stance in regard to clinical recovery (Tiderington 2015; Austin, Pollio and Kertesz 2016). While this passivity may appear aligned with the removal of preconditions to housing entry, it fits poorly with the aspiration that Housing First be a clinical endeavour and not just a housing program (Tsemberis 2010).

\section{Evidence from North America}

\subsection{Housing Outcomes}

Studies of effectiveness of Housing First have considered housing outcomes, clinical status indicators and economic expenditures, with varying results. One systematic review identified 14 studies based on 12 randomised controlled trials, with 11 trials demonstrating superior housing outcomes for persons receiving a Housing First-like intervention. For example, a Canadian multi-site randomised controlled trial involving 1,198 homeless persons with moderate-level needs (the Chez Soi study) reported that at 2 years' follow-up, persons in the intervention group achieved 63-77 per cent 
of time housed in the prior 24 months, compared to 24-39 per cent in the 'usual care group' (Stergiopoulos et al. 2015). These results differed little from an earlier small randomised controlled trial in New York (Tsemberis, Gulcur and Nakae 2004). At present, just one study assessed outcomes for longer than 4 years (which were favourable) (Stefancic and Tsemberis 2007).

Favourable housing results should not obscure some scientific limitations (Benston 2015). Most studies suffer from imprecise definitions of the housing intervention and inconsistencies in entry or eligibility criteria. Attrition has been relatively high. Outcomes are often self-reported, which has some limitations. Studies have not consistently designated their interventions as 'Housing First' and few evaluated fidelity of the housing intervention. The net impact of these limitations is that policy-makers embracing Housing First should attend to fidelity of implementation or they risk outcomes worse than those reported from trials.

\subsection{Clinical Impacts}

The relationship between homelessness and poor health is often bi-directional, with poor mental or physical health contributing to homelessness and homelessness standing in the way of successful restoration of health. Randomised trials have typically found no or minimal benefit for standard health measures (Sadowski et al. 2009; Benston 2015; Stergiopoulos et al. 2015; Aubry et al. 2016). Indeed, most studies show improvement both for individuals entering the housing intervention and for individuals entering traditional programs.

Despite negative findings for typical physical and mental health measures, it is premature to suggest that Housing First interventions confer no clinical benefit. First, This article is protected by copyright. All rights reserved 
most such studies assess outcomes at 1-2 years. It could take longer for recovery to take effect. Additionally, some positive results are reported in control of HIV (Buchanan et al. 2009) and in indicators of community functioning or well-being (O'Campo et al. 2016). Additionally, one Chez Soi trial site reported reductions in alcohol use (Kirst et al. 2015). Finally, persons entering housing programs include many who are quite sick. A significant number die in housing shortly after moving in (Henwood, Byrne and Scriber 2015). Future studies of Housing First will need to carefully consider how this 'already quite sick' group influences analysis.

\subsection{Economic Claims}

It is often claimed that it is cheaper to house chronically homeless persons than to leave them homeless (Gladwell 2006). Indeed, one organisation reported that providing 'permanent housing for chronically homeless individuals costs one third the cost of leaving these individuals on the streets'. ${ }^{1}$ While politically appealing, these and other similar claims reflect weak study designs.

More rigorous studies sometimes show credible cost offsets in regard to emergency department and inpatient use, justice system involvement and the use of other welfare services. However, findings are inconsistent. Some studies report a decline in service use, relative to either a comparison group (Gulcur et al. 2003; Larimer et al. 2009; Sadowski et al. 2009; Basu et al. 2012) and/or pre-intervention levels (Culhane, Metraux and Hadley 2002; Martinez and Burt 2006). Conversely, the large multi-site randomised trial from Canada, Chez Soi, reported no trial arm difference in service use, a difference that might reflect the comparative generosity 
of Canadian health service delivery to both trial arms (Stergiopoulos et al. 2015; Aubry et al. 2016).

The two studies to report overall net cost savings (Gulcur et al. 2003; Basu et al. 2012) had limitations. One assumed that averting a day of hospitalisation saved US $\$ 7,485$, a figure that exceeds any mainstream estimate for hospital costs in a way that inflated apparent savings (Basu et al. 2012). A few studies assume that housing costs can be allocated on a per-day basis (Culhane, Metraux and Hadley 2002; Gulcur et al. 2003; Basu et al. 2012), when housing programs accrue expenses even when clients are absent from apartments.

In sum, for all but the most 'expensive' chronically homeless persons, cost savings do not exceed the cost of providing Housing First (Culhane, Metraux and Hadley 2002; Kertesz et al. 2016). The strongest evidence of this comes from the Canadian Chez Soi trial that involved 2,000 participants. Goering et al. (2014) reported that for every $\mathrm{C} \$ 10$ invested in Housing First services, savings were $\mathrm{C} \$ 9.32$ for high-need clients and $\mathrm{C} \$ 3.42$ for moderate-need participants. Importantly, highneed clients accounted for only 10 per cent of the sample. Housing First can almost 'pay for itself', but only when it targets a costly clientele who represent only a very small portion of the chronically homeless. In summary, the economic impact of Housing First is important but probably not as large as is often claimed.

\section{Housing First in Australia}

Australian interest in Housing First initiatives gathered momentum in 2008 when, as part of the white paper on homelessness called 'The Road Home: A National 
Approach to Reducing Homelessness' (Department of Families, Housing, Community Services and Indigenous Affairs 2008), the federal government committed to offering supported accommodation to all rough sleepers by 2020 . Seizing on evidence from the United States, the government committed to funding 'Street to Home' scattered-site housing programs, as well as 'Common Ground' congregate facilities in every state and territory. This represented a radical departure from what was possible under prior service arrangements and confirmed the government's willingness to try new approaches. The latter decision, however, emerged less from research data and more from 'intuition and direct personal experiences' (Parsell, Fitzpatrick and Busch-Geertsema 2014).

Street to Home projects in Melbourne, Sydney and Brisbane target chronically homeless individuals, based on vulnerability to premature death, using a Vulnerability Index tool (OrgCode Consulting, Inc. and Community Solutions 2015). Whether such tools represent a scientifically defensible method of allocating resources, however, remains disputed (National Alliance to End Homelessness and Office of Policy Development and Research, U.S. Department of Housing and Urban Development 2015). Despite the presence of Street to Home and Common Ground facilities in every state, most have not been subject to any form of rigorous, public evaluation. Also, although some evaluations use longitudinal designs, these have typically been limited to tracking participants for 1 year (Parsell, Tomaszewski and Jones 2013) or 2 years (Johnson and Chamberlain 2015). Only one Australian study imposed a randomised controlled trial methodology to assess impact (Johnson et al. 2014). Although they did not explicitly label the Journey to Social Inclusion program 'Housing First', the program shares similarities with a Housing First approach. 
Despite these evidentiary limitations, results thus far echo findings from overseas: these include strong, statistically significant housing outcomes and reductions in intensity and frequency of service use relative to pre-intervention levels, although these are not always statistically significant. Similar to overseas research, Australian studies report little behavioural change, particularly in regard to addiction and illicit drug use. Similarly purported economic savings are smaller than claimed. The Journey to Social Inclusion trial, which involved just under 100 participants, reported that for every $A \$ 1$ invested, there was a $A \$ 0.32$ return to the community (Johnson et al. 2014).

Although there is a clear need to improve the Australian evidence base for Housing First, there are other equally important questions to address. First, there remain considerable differences in how Australian Housing First programs operate. This raises the question of whether there should be a 'standard' Housing First model or set of operational standards to which all Australian Housing First services should conform. These issues foreshadow a second question: How might Australian policymakers and service providers best manage the tension between program fidelity and adaptations to local conditions to ensure that program outcomes remain high? Australia's social, economic and cultural conditions differ markedly from the United States and the development of Australian Housing First models should reflect these differences. However, the development of a unique Australian Housing First model should identify and articulate the key elements of these models that help to sustain housing and clinical improvements.

\section{Conclusion}


A Housing First approach has much to offer. The evidence from overseas and, to a lesser extent from Australia, show that Housing First has disrupted settled assumptions about the capacity of chronically homeless persons to maintain housing. The success of Housing First has led to worldwide interest. Housing First services can be found in many countries including France, Finland, England, Germany, as well as in Australia.

In the processes of transferring Housing First to different countries, it is equally clear that there are now diverse views on what constitute the core components of a Housing First approach (Johnson, Parkinson and Parsell 2012). Whether local adaptations of the Housing First model reflect enhancements or represent 'unwelcome model drift' (Stefancic et al. 2013, p. 242) has yet to be established. Also, even in instances where the desired instantiation of Housing First is well articulated, there are challenges to implementing the approach with sufficient support for clients and landlords. The drift away from many of the original concepts, coupled with limited appreciation of the challenges to effective implementation of the model, has created a risk of underperformance. If underperformance is accompanied by outsized claims regarding the economic or health benefits Housing First can deliver, then there is risk of policy overreach. The outcome of such overreach is, customarily, blowback and recrimination if and when promised benefits do not emerge.

Against these risks, however, lies a promising array of benefits in terms of housing outcomes, clinical gains and community benefits that result from alleviation of homelessness. Finally, Housing First aligns plausibly with a moral posture that prioritises efforts to remediate the plight of the communities' most vulnerable citizens. 
February 2017

\section{References}

Aubry, T., Goering, P., Veldhuizen, S., Adair, C. E., Bourque, J., Distasio, J., Latimer, E., Stergiopoulos, V., Somers, J., Streiner, D. L. and Tsemberis, S. 2016, 'A multiple-city RCT of Housing First with assertive community treatment for homeless Canadians with serious mental illness', Psychiatric Services, vol. 67, pp. 275-81.

Austin, E. L., Pollio, D. E., Holmes, S., Schumacher, J., White, B., Lukas, C. V. and Kertesz, S. 2014, 'VA's expansion of supportive housing: Successes and challenges on the path toward Housing First', Psychiatric Services, vol. 65, pp. 641-7.

Austin, E. L., Pollio, D. E. and Kertesz, S. G. 2016, 'Ethnographic observation of a Housing First approach to case management at four VA medical centers', Psychiatric Services, vol. 67 , pp. 1,384-5.

Australian Bureau of Statistics 2012, Census of Population and Housing: Estimating Homelessness, Cat. no. 2049.0, ABS, Canberra.

Baggett, T. P., Hwang, S. W., O'Connell, J. J., Porneala, B. C., Stringfellow, E. J., Orav, E. J., Singer, D. E. and Rigotti, N. A. 2013, 'Mortality among homeless adults in Boston: Shifts in causes of death over a 15-year period', JAMA Internal Medicine, vol. 173, pp. 189-95.

Basu, A., Kee, R., Buchanan, D. and Sadowski, L. 2012, 'Comparative cost analysis of housing and case management program for chronically homeless adults compared to usual care', Health Services Research, vol. 47, pp. 523-43.

Benston, E. A. 2015, 'Housing programs for homeless individuals with mental illness: Effects on housing and mental health outcomes', Psychiatric Services, vol. 66, pp. 806-16.

Buchanan, D., Kee, R., Sadowski, L. S. and Garcia, D. 2009, 'The health impact of supportive housing for HIV-positive homeless patients: A randomized controlled trial', American Journal of Public Health, vol. 99, suppl. 3, pp. S675-80.

Busch-Geertsema, V. 2014, 'Housing First Europe - Results of a European social experimentation project', European Journal of Homelessness, vol. 8, no. 1, pp. 13-28.

Collins, S. E., Clifasefi, S. L., Andrasik, M. P., Dana, E. A., Stahl, N., Kirouac, M., Welbaum, C., King, M. and Malone, D. K. 2012, 'Exploring transitions within a project-based Housing First setting: Qualitative evaluation and practice implications', Journal of Health Care for the Poor and Underserved, vol. 23, pp. 1,678-97. 
Culhane, D., Metraux, S. and Hadley, T. 2002, 'Public service reductions associated with placement of homeless persons with severe mental illness in supportive housing', Housing Policy Debate, vol. 13, pp. 107-63.

Department of Families, Housing, Community Services and Indigenous Affairs 2008, The Road Home: A National Approach to Reducing Homelessness, FaHCSIA, Canberra. Durlak, J. A. and DuPre, E. P. 2008, 'Implementation matters: A review of research on the influence of implementation on program outcomes and the factors affecting implementation', American Journal of Community Psychology, vol. 41, pp. 327-50.

Gilmer, T. P., Stefancic, A., Henwood, B. F. and Ettner, S. L. 2015, 'Fidelity to the Housing First model and variation in health service use within permanent supportive housing', Psychiatric Services, vol. 66, pp. 1,283-9.

Gladwell, M. 2006, 'Million-dollar Murray: Why problems like homelessness may be easier to solve than to manage', New Yorker, vol. 81, pp. 96-107.

Goering, P., Veldhuizen, S., Watson, A., Adair, C., Kopp, B., Latimer, E., Nelson, G., Macnaughton, E., Streiner, D. and Aubry, T. 2014, National At Home/Chez Soi Final Report, Mental Health Commisson of Canada, Calgary.

Gulcur, L., Stefanie, D., Shinn, M., Tsemberis, S. and Fischer, S. 2003, 'Housing, hospitalisation, and cost outcomes for homeless individuals with psychiatric disabilities participating in Continuum of Care and Housing First programmes', Journal of Community and Applied Social Psychology, vol. 13, pp. 171-86.

Henwood, B. F., Byrne, T. and Scriber, B. 2015, 'Examining mortality among formerly homeless adults enrolled in Housing First: An observational study', BMC Public Health, vol. 15, p. 1,209.

Johnsen, S. and Teixeira, L. 2010, Staircases, Elevators and Cycle of Change: 'Housing First' and Other Housing Models for Homeless People with Complex Needs, Crisis, London.

Johnson, G. and Chamberlain, C. 2015, Evaluation of the Melbourne Street to Home Program: Final Report, HomeGround Services and The Salvation Army, Melbourne.

Johnson, G., Kuehnle, D., Parkinson, S., Sesa, S. and Tseng, Y. 2014, Sustaining Exits from Long-Term Homelessness: A Randomised Controlled Trial Examining the 48 Month Social and Economic Outcomes from the Journey to Social Inclusion Pilot Pogram, Sacred Heart Mission, Melbourne.

Johnson, G., Parkinson, S. and Parsell, C. 2012, Policy Shift or Program Drift: Implementing Housing First in Australia, Australian Institute of Housing and Urban Research, Melbourne.

Kertesz, S. G., Austin, E. L., Holmes, S. K., Pollio, D. E., Schumacher, J. E., White, B. and VanDeusen Lukas, C. 2014, 'Making Housing First happen: Organizational leadership 
in VA's expansion of permanent supportive housing', Journal of General Internal Medicine, vol. 29, suppl. 4, pp. 835-44.

Kertesz, S. G., Austin, E. L., Holmes, S. K., Pollio, D. E. and VanDeusen Lukas, C. 2015, 'Housing First and the risk of failure: A comment on Westermeyer and Lee (2013)', Journal of Nervous and Mental Disease, vol. 203, pp. 559-62.

Kertesz, S. G., Baggett, T. P., O’Connell, J. J., Buck, D. S. and Kushel, M. B. 2016, 'Permanent supportive housing for homeless people - Reframing the debate', New England Journal of Medicine, vol. 375, pp. 2,115-17.

Kertesz, S., Crouch, K., Milby, J., Cusimano, R. and Schumacher, J. 2009, 'Housing First for homeless persons with active addiction: Are we overreaching?', Milbank Quarterly, vol. 87, pp. 495-534.

Kertesz, S. G., Mullins, A. N., Schumacher, J. E., Wallace, D., Kirk, K. and Milby, J. B. 2007, 'Long-term housing and work outcomes among treated cocaine-dependent homeless persons', Journal of Behavioral Health Services and Research, vol. 34, pp. 17-33.

Kirst, M., Zerger, S., Misir, V., Hwang, S. and Stergiopoulos, V. 2015, 'The impact of a Housing First randomized controlled trial on substance use problems among homeless individuals with mental illness', Drug and Alcohol Dependence, vol. 146, pp. 24-9.

Larimer, M., Malone, D., Garner, M., Atkins, D., Burlingham, B., Lonczak, H., Tanzer, K., Ginzler, J., Clifasefi, S., Hobson, W. and Marlatt, G. 2009, 'Health care and public service use and costs before and after provision of housing for chronically homeless persons with severe alcohol problems', JAMA, vol. 301, pp. 1,349-57.

Lipton, F. R., Siegel, C., Hannigan, A., Samuels, J. and Baker, S. 2000, 'Tenure in supportive housing for homeless persons with severe mental illness', Psychiatric Services, vol. 51, pp. 479-86.

Macnaughton, E., Stefancic, A., Nelson, G., Caplan, R., Townley, G., Aubry, T., McCullough, S., Patterson, M., Stergiopoulos, V., Vallee, C., Tsemberis, S., Fleury, M. J., Piat, M. and Goering, P. 2015, 'Implementing Housing First across sites and over time: Later fidelity and implementation evaluation of a pan-Canadian multi-site Housing First program for homeless people with mental illness', American Journal of Community Psychology, vol. 55, pp. 279-91.

Martinez, T. and Burt, M. 2006, 'Impact of permanent supportive housing on the use of acute care health services by homeless adults', Psychiatric Services, vol. 57, pp. 992-9.

Miller, W. R. and Rollnick, S. 2004, Motivational Interviewing: Preparing People for Change, 2nd edn, Guilford Press, New York.

National Alliance to End Homelessness and Office of Policy Development and Research, U.S. Department of Housing and Urban Development 2015, Assessment Tools for Allocating Homelessness Assistance: State of the Evidence, Office of Policy

This article is protected by copyright. All rights reserved 
Development and Research, U.S. Department of Housing and Urban Development, Washington, DC.

O'Campo, P., Stergiopoulos, V., Nir, P., Levy, M., Misir, V., Chum, A., Arbach, B., Nisenbaum, R., To, M. J. and Hwang, S. W. 2016, 'How did a Housing First intervention improve health and social outcomes among homeless adults with mental illness in Toronto? Two-year outcomes from a randomised trial', BMJ Open, vol. 6, no. 9, p. e010581.

O'Connell, M., Kasprow, W. and Rosenheck, R. 2009, 'Direct placement versus multistage models of support housing in a population of veterans who are homeless',

Psychological Services, vol. 6, pp. 190-201.

Office of Community Planning and Development 2016, The 2016 Annual Homeless Assessment Report (AHAR) to Congress (Part 1), U.S. Department of Housing and Urban Development, Washingon, DC.

OrgCode Consulting, Inc. and Community Solutions 2015, Vulnerability Index - Service Prioritization Decision Assistance Tool (VI-SPDAT) Prescreen Triage Tool for Single Adults (American Version 2.0), OrgCode Consulting, Inc., Oakville, Ontario.

Parsell, C. 2014, 'Chronic homelessness: A political and moral priority', in Homelessness in Australia: An Introduction, eds C. Chamberlain, G. Johnson and C. Robinson, UNSW Press, Sydney.

Parsell, C., Fitzpatrick, S. and Busch-Geertsema, V. 2014, 'Common ground in Australia: An object lesson in evidence hierarchies and policy transfer', Housing Studies, vol. 29, pp. 69-87.

Parsell, C., Tomaszewski, T. and Jones, A. 2013, An Evaluation of Brisbane Street to Home: Final Report, Department of Families, Housing, Community Services and Indigenous Affairs, Canberra.

Sadowski, L., Kee, R., Vanderweele, T. and Buchanan, D. 2009, 'Effect of a housing and case management program on emergency department visits and hospitalizations among chronically ill homeless adults: A randomized trial', JAMA, vol. 301, pp. 1,7718.

Stefancic, A. and Tsemberis, S. 2007, 'Housing First for long-term shelter dwellers with psychiatric disabilities in a suburban county: A four-year study of housing access and retention', Journal of Primary Prevention, vol. 28, pp. 265-79.

Stefancic, A., Tsemberis, S., Messeri, P., Drake, R. and Goering, P. 2013, 'The Pathways Housing First fidelity scale for individuals with psychiatric disabilities', American Journal of Psychiatric Rehabilitation, vol. 16, pp. 240-61.

Stergiopoulos, V., Hwang, S. W., Gozdzik, A., Nisenbaum, R., Latimer, E., Rabouin, D., Adair, C. E., Bourque, J., Connelly, J., Frankish, J., Katz, L. Y., Mason, K., Misir, V., 
O’Brien, K., Sareen, J., Schutz, C. G., Singer, A., Streiner, D. L., Vasiliadis, H. M. and Goering, P. N. 2015, 'Effect of scattered-site housing using rent supplements and intensive case management on housing stability among homeless adults with mental illness: A randomized trial', JAMA, vol. 313, pp. 905-15.

Tabol, C., Drebing, C. and Rosenheck, R. 2010, 'Studies of "supported" and "supportive" housing: A comprehensive review of model descriptions and measurement', Evaluation and Program Planning, vol. 33, pp. 446-56.

Tiderington, E. 2015, “'We always think you're here permanently”: The paradox of "permanent" housing and other barriers to recovery - Oriented practice in supportive housing services', Administration and Policy in Mental Health, vol. 44, pp. 103-14.

Tsemberis, S. 2010, 'Housing First: Ending homelessness, promoting recovery and reducing cost', in How to House the Homeless, eds I. Ellen and B. O'Flaherty, Russell Sage Foundation, New York.

Tsemberis, S, Gulcur, L and Nakae, M. 2004, 'Housing First, consumer choice, and harm reduction for homeless individuals with a dual diagnosis', American Journal of Public Health, vol. 94, pp. 651-6.

\section{Endnote}

1. See <https://cmtysolutions.org/sites/default/files/housingfirstfactsheet-zero2016.pdf>. 


\section{University Library}

\section{- M M I N E R VA A gateway to Melbourne's research publications}

Minerva Access is the Institutional Repository of The University of Melbourne

Author/s:

Kertesz, SG;Johnson, G

Title:

Housing First: Lessons from the United States and Challenges for Australia

Date:

2017-06-01

Citation:

Kertesz, S. G. \& Johnson, G. (2017). Housing First: Lessons from the United States and Challenges for Australia. The Australian Economic Review, 50 (2), pp.220-228. https:// doi.org/10.1111/1467-8462.12217.

Persistent Link:

http://hdl.handle.net/11343/292969 